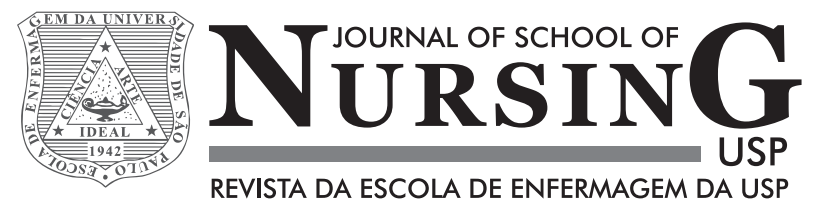

\title{
The influence of quality of life in treatment adherence of diabetic patients: a systematic review*
}

\author{
A influência da qualidade de vida na adesão ao tratamento \\ do paciente diabético: revisão sistemática \\ La influencia de la calidad de vida en la adhesión al tratamiento \\ del paciente diabético: revisión sistemática
}

Luana de Fátima Gusmai ${ }^{1,}$ Tatiana de Sá Novato ${ }^{2,}$ Lilia de Souza Nogueira $^{3}$

\footnotetext{
Extracted from the final residency paperwork "A influência da qualidade de vida na adesão ao tratamento do paciente diabético: revisão sistemática”, Programa de Residência em Enfermagem na Saúde do Adulto e do Idoso, Escola de Enfermagem, Universidade de São Paulo, 2014.

${ }^{1}$ Universidade de São Paulo, Escola de Enfermagem, Programa de Residência em Enfermagem na Saúde do Adulto e do Idoso, São Paulo, SP, Brazil.

${ }^{2}$ Universidade Paulista, São Paulo, SP, Brazil.

${ }^{3}$ Universidade de São Paulo, Escola de Enfermagem, Departamento de Enfermagem Médico-Cirúrgica, São Paulo, SP, Brazil.
}

\section{ABSTRACT}

Objective: To verify the influence of quality of life in treatment adherence of patients with diabetes mellitus. Method: Systematic review of the literature using the databases MEDLINE, CINAHL, Scopus, LILACS, SciELO and Web of Science with studies published between 2003 and 2014 in English, Portuguese or Spanish. Results: Six studies were included in the review, three were identified as having better quality of life scores, being related to better adherence to diabetes treatment measured by glycated hemoglobin or characteristics related to diet, exercise, use of medication and foot care. No association was found between quality of life and adherence in two investigations and a study found a negative association between these variables. Conclusion: There is causal relationship between quality of life and adherence with diabetes treatment. It is suggested that psychosocial aspects of patients should be considered by health professionals in the search for better clinical outcomes in diabetes care.

\section{DESCRIPTORS}

Diabetes Mellitus; Quality of Life; Patient Compliance; Medication Adherence; Review. 


\section{INTRODUCTION}

Diabetes Mellitus (DM) is a public health problem due to its increased incidence and prevalence ${ }^{(1)}$. Being a chronic disease that requires long-term monitoring and individual care to prevent complications, DM is associated with high economic and social costs to individuals, families and society ${ }^{(1)}$.

According to the World Health Organization (WHO), approximately 347 million people worldwide have diabetes, and $80 \%$ of deaths from this disease occur in low - or middle-income countries like Brazil ${ }^{(2)}$.

Studies show that quality of life (QOL) of patients with DM can influence treatment adherence, satisfactorily improving clinical outcomes and reducing the morbidity and mortality rates and disease progression ${ }^{(3-6)}$. The literature suggests that the physical and emotional conditions under which the individual with DM is inserted emerge as important factors in determining their behavior related to treatment adherence ${ }^{(7)}$. As an example, it can be said that excessive increase of stress in individuals with DM, as well as interpersonal and environmental factors, negatively interfere with their behavior related to treatment adherence ${ }^{(7)}$.

The evaluation of the patient's QOL is recognized as an important area of scientific knowledge, since the concept of QOL relates to the notion of health: satisfaction and wellbeing in the physical, psychological, socio-economic and cultural spheres ${ }^{(8)}$. According to the WHO, QOL can be defined as individuals perception of their position in life in the context of the culture and value systems in which they live in and in relation to their goals, expectations, standards and concerns ${ }^{(9)}$.

Because of the complexity involved in DM, factors related to the patient, such as emotional aspects and life history need to be taken into account in serving this group, since they are essential to the treatment and prevention of chronic complications that the disease can generate ${ }^{(10)}$.

The analysis of the relationship between QOL and treatment adherence is still contradictory in the literature. Some studies ${ }^{(11-13)}$ show that the best QOL of patients with $\mathrm{DM}$ is associated with better treatment adherence of the disease; however, another research has not found this association $^{(14)}$. Given this context of uncertainty and assuming that QOL may influence treatment adherence of individuals with DM, we propose this study, which aims to find the evidence about the influence of QOL in treatment adherence of patients with DM.

\section{METHOD}

This is a systematic review of the literature, defined as a form of research that uses as data, the literature on a particular topic. This type of research should be developed through the application of systematic search methods, critical appraisal and synthesis of the included information ${ }^{(15)}$.

The search was conducted between the months of September to December 2014 in the databases: Latin American databases and Caribbean Health Sciences (LILACS), Medical Literature Analysis and Retrieval System online (MEDLINE), Cumulative Index to Nursing and Allied Health Lit- erature (CINAHL), SCOPUS, Scientific Electronic Library Online (SciELO) and Thomson Reuters Web of Science.

The guiding question of this review is: Does the quality of life of individuals with DM influence treatment adherence of the disease?. We used the PICO strategy for the construction of the research question, which is an acronym for Patient, Intervention, Comparison and Outcomes. These four components are the key elements of the research question for the search of evidence in the databases ${ }^{(16)}$. The $\mathrm{C}$ element of PICO was not used since the objective of this review did not include the comparison of different interventions.

The descriptors used in the search were selected from the Health Sciences Descriptors (DeCS), Medical Subject Headings (MeSH) and titles CINAHL. According to the PICO strategy, the following components were considered: diabetes, diabetes mellitus, type 1; diabetes mellitus, type 2 (to the patient); quality of life and lifestyle (for intervention); patient compliance and adherence to medication (for outcome).

The descriptors and titles CINAHL were combined with the boolean operators "OR" and "AND". Since the databases have different characteristics and specificities, the search was performed using different strategies, as described in Chart 1.

Chart 1 - Search strategies for databases - São Paulo, SP, Brazil, 2015.

\begin{tabular}{|c|c|}
\hline Databases & Search strategies \\
\hline LILACS & $\begin{array}{l}\text { (tw:(diabetes mellitus)) OR (tw:(diabetes mellitus tipo 1)) } \\
\text { OR (tw:(diabetes mellitus tipo 2)) AND (tw:(qualidade } \\
\text { de vida)) AND (tw:(cooperação do paciente)) OR } \\
\text { (tw:(adesão a medicação)) }\end{array}$ \\
\hline $\begin{array}{l}\text { MEDLINE } \\
\text { (via } \\
\text { PubMed) }\end{array}$ & $\begin{array}{l}\text { (((("diabetes mellitus, type 2"[MeSH Terms] OR "type } 2 \\
\text { diabetes mellitus"[All Fields] OR "diabetes mellitus, type } \\
\text { 2"[All Fields]) OR ("diabetes mellitus, type 1"[MeSH } \\
\text { Terms] OR "type } 1 \text { diabetes mellitus"[All Fields] OR } \\
\text { "diabetes mellitus, type 1"[All Fields])) OR ("diabetes } \\
\text { mellitus"[MeSH Terms] OR ("diabetes"[All Fields] } \\
\text { AND "mellitus"[All Fields]) OR "diabetes mellitus"[All } \\
\text { Fields])) AND (("life style"[MeSH Terms] OR ("life"[All } \\
\text { Fields] AND "style"[All Fields]) OR "life style"[AIl Fields] } \\
\text { OR "lifestyle"[All Fields]) OR ("quality of life"[MeSH } \\
\text { Terms] OR ("quality"[All Fields] AND "life"[All Fields]) } \\
\text { OR "quality of life"[AIl Fields]))) AND (("patient } \\
\text { compliance"[MeSH Terms] OR ("patient"[All Fields] AND } \\
\text { "compliance"[All Fields]) OR "patient compliance"[All } \\
\text { Fields]) OR ("medication adherence"[MeSH Terms] OR } \\
\text { ("medication"[All Fields] AND "adherence"[All Fields]) } \\
\text { OR "medication adherence"[All Fields])) }\end{array}$ \\
\hline CINAHL & $\begin{array}{l}\text { (MH "Diabetes Mellitus") OR (MH "Diabetes Mellitus, } \\
\text { Type 2") OR (MH "Diabetes Mellitus, Type 1" AND (MH } \\
\text { "Quality of Life") AND (MH "Patient Compliance") OR } \\
\text { (MH "Medication Compliance") }\end{array}$ \\
\hline SCOPUS & $\begin{array}{l}\text { (TITLE-ABS-KEY (diabetes mellitus) OR TITLE-ABS-KEY } \\
\text { (diabetes mellitus,type 1) OR TITLE-ABS-KEY (diabetes } \\
\text { mellitus,type 2) AND TITLE-ABS-KEY (quality of life) } \\
\text { AND TITLE-ABS-KEY (patient compliance) OR TITLE- } \\
\text { ABS-KEY (medication adherence)) }\end{array}$ \\
\hline SciELO & $\begin{array}{l}\text { (diabetes mellitus) OR (diabetes mellitus type 1) OR } \\
\text { (diabetes mellitus type 2) AND (quality of life) AND } \\
\text { (patient compliance) OR (medication adherence) }\end{array}$ \\
\hline $\begin{array}{l}\text { Web of } \\
\text { Science }\end{array}$ & $\begin{array}{l}\text { (("diabetes mellitus" OR "diabetes mellitus type } 1 \text { " OR } \\
\text { "diabetes mellitus type 2") AND quality of life AND } \\
\text { ("patient compliance" OR "medication adherence")) }\end{array}$ \\
\hline
\end{tabular}

Primary and secondary studies available in full, published in national and international journals between 2003 and 2014 in English, Spanish or Portuguese languages and 
that addressed the association between QOL of adult patients (over 18 years) with DM (type 1 and/or 2) and treatment adherence of disease were included.

Book chapters, editorials, case series, comments, theses and dissertations and studies that addressed gestational diabetes or pre-diabetes were excluded from the sample.

The selection of studies was made through the assessment of the titles, followed by reading of the abstracts and then evaluation of studies in full. For extracting data from the studies, we developed two instruments. The first contained the following information: title, author, objectives, study type, publication year and country. The second addressed the DM type, population, group most affected by gender, QOL assessment instrument, adherence assessment and relationship between QOL treatment adherence.

The quality assessment of studies design was performed independently by two reviewers using the instrument application Strengthening the Reporting of Observational Studies in Epidemiology (STROBE), a checklist containing 22 items with recommendations about what should be included in a more precise and full description of observational studies ${ }^{(17)}$. This analysis was only descriptive, that is, not aimed at the exclusion of the sample studies.

The data are presented in figures and Boxes and the results in a descriptive way, they are also compared and evaluated for their applicability.

\section{RESULTS}

From the searches in the databases and using the eligibility criteria, six studies were included in the final sample. Figure 1 shows the study selection process.

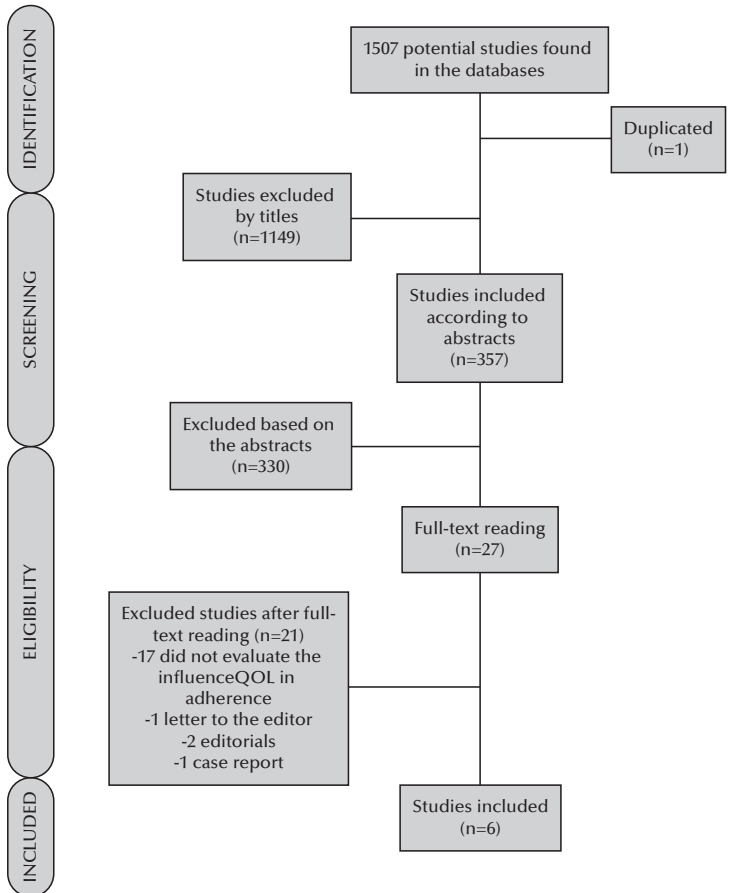

Figure 1 - Flowchart of study selection process, Sao Paulo, SP, Brazil, 2015

As the method used, 1507 potential studies were identified from the search strategies, and the Medline database showed the majority of studies (53.0\%), followed by LI-
LACS (18.7\%), CINAHL (9.6\%), SCOPUS (9.0\%), SciELO (5.0\%) and Web of Science (4.7\%).

Of the six studies that composed the final sample, five $(83,3 \%)^{(18-22)}$ were found in MEDLINE and one $(16,7 \%)^{(23)}$ in CINAHL.

It is observed in Chart 2 that no study had agreement with all items in the STROBE. However, all the items that composed the final sample of this review have attended at least $50 \%$ of the items of the STROBE and the agreement among reviewers ranged from 13 to 20 (59.1 to 90.9\%) of the checklist items.

Two studies ${ }^{(19,21)}$ were performed in the United States, one in Thailand ${ }^{(18)}$, one in Singapure ${ }^{(23)}$, one in Mexico ${ }^{(22)}$ and another one in Netherlands ${ }^{(20)}$. The surveys were conducted between 1998 and 2009 and published from 2004 to 2012. English was the language found in all investigations, as well as the observational study design.

Chart 3 shows that the sample/population ranged from 111 to 1149 individuals, and the female gender was predominant in the studies. Considering the total of $2060 \mathrm{pa}^{-}$ tients analyzed, it can be said that the majority (56.8\%) were women. The type $2 \mathrm{DM}$ was investigated in all studies and only two studies also included patients with type $1 \mathrm{DM}$ in their analysis. The age of participants ranged from 21 to 97 years and the mean 44.7 to 68.7 years.

Note in Chart 4 that QOL was measured by different instruments: the generics, like The 36-Item Short Form Health Survey (SF-36), the 12-Item Short-Form Health Survey (SF-12), World Health Organization Quality of Life instrument (WHOQOL-100), The World Health Organization's WHOQOL-BREF quality of life assessment (WHOQOL - bref) and 5-D EuroQol (EQ-5D), and the specific ones as the Audit of Diabetes-dependent quality of Life (ADDQoL), used to assess QOL in diabetics, and The RAND-36 Measure of Health-Related Quality of Life (Rand-36), which evaluates health-related quality of life.

The test of glycated hemoglobin (A1c) was used exclusively as adherence measure in three studies ${ }^{(20-21,23)}$. One study ${ }^{(22)}$ analyzed the tablet counts associated with the knowledge of the disease. Another study ${ }^{(18)}$ used the dietary control with exercise, use of medication and foot care as adherence measures for the treatment of diabetes. Guidelines from American Diabetes Association of 2005 suggest the analysis of treatment adherence of participants: two tests for A1c, a test for cholesterol, one microalbuminuria test and an eye examination in one year period ${ }^{(19)}$.

The relationship between QOL and treatment adherence of patients with DM was found in four (66.7\%) studies $^{(18-19,21,23)}$. Two studies $(33,3 \%)^{(20,22)}$ found no association between these variables.

The USA studies have shown different results: a research that analyzed 111 diabetics type 1 or 2 identified that patients with lower scores in the mental health domain of the SF-12 did better in controlling diabetes ${ }^{(19)}$. Another study showed, in a population of 1,116 patients, the $1 \%$ increase in the scores of the mental health domain of the SF-36 was related to the $5 \%$ decrease of the A1c values ${ }^{(21)}$. 
Chart 2 - Distribution of studies by title, objective, study design, year and country - São Paulo, SP, Brazil, 2015.

\begin{tabular}{|c|c|c|c|c|}
\hline $\begin{array}{l}\text { Study identification and } \\
\text { number of items STROBE }\end{array}$ & Title & Objective & Study design & $\begin{array}{l}\text { Year, } \\
\text { country }\end{array}$ \\
\hline $\begin{array}{l}\text { Study } 1(\mathrm{~S} 1) \\
\text { STROBE:20 items }\end{array}$ & $\begin{array}{l}\text { Health-related quality of life and gly- } \\
\text { cemic control in patients with Type } 2 \\
\text { diabetes mellitus in Singapore }^{(23)}\end{array}$ & $\begin{array}{l}\text { To investigate the quality of life related } \\
\text { to health of patients with diabetes } \\
\text { mellitus in Singapore and its associa- } \\
\text { tion with the DM characteristics and } \\
\text { glycemic control }\end{array}$ & $\begin{array}{l}\text { Observational, } \\
\text { cross-sectional }\end{array}$ & $\begin{array}{l}\text { 2012, } \\
\text { Singapure }\end{array}$ \\
\hline $\begin{array}{l}\text { Study } 2 \text { (S2) } \\
\text { STROBE: } 19 \text { items }\end{array}$ & $\begin{array}{l}\text { Quality of life associated with treat- } \\
\text { ment adherence in patients with type } \\
2 \text { diabetes: a cross-sectional study }{ }^{(22)}\end{array}$ & $\begin{array}{l}\text { To evaluate the association between } \\
\text { QOL and the adherence behavior to } \\
\text { treatment, knowledge of the prescrip- } \\
\text { tion and the attitude towards treatment } \\
\text { adherence }\end{array}$ & $\begin{array}{l}\text { Observational, } \\
\text { cross-sectional } \\
\text { comparative }\end{array}$ & $\begin{array}{l}2008, \\
\text { Mexico }\end{array}$ \\
\hline $\begin{array}{l}\text { Study } 3(\mathrm{~S} 3) \\
\text { STROBE: } 11 \text { items }\end{array}$ & $\begin{array}{l}\text { Quality of life and compliance } \\
\text { among type } 2 \text { diabetic patients }{ }^{(18)}\end{array}$ & $\begin{array}{l}\text { To explore the quality of life of pa- } \\
\text { tients with type } 2 \text { DM and relate it to } \\
\text { compliance with treatment }\end{array}$ & $\begin{array}{l}\text { Observational, } \\
\text { transversal }\end{array}$ & $\begin{array}{l}2008, \\
\text { Thailand }\end{array}$ \\
\hline $\begin{array}{l}\text { Study } 4 \text { (S4) } \\
\text { STROBE: } 14 \text { items }\end{array}$ & $\begin{array}{l}\text { Health-related quality of life and } \\
\text { treatment compliance with diabetes } \\
\text { care }^{(19)}\end{array}$ & $\begin{array}{l}\text { To explore the relationship between } \\
\text { quality of life and treatment adherence }\end{array}$ & $\begin{array}{l}\text { Observational, } \\
\text { longitudinal }\end{array}$ & $\begin{array}{l}\text { 2006, } \\
\text { USA }\end{array}$ \\
\hline $\begin{array}{l}\text { Study } 5 \text { (S5) } \\
\text { STROBE: } 19 \text { items }\end{array}$ & $\begin{array}{l}\text { Cross-sectional relationship between } \\
\text { glycemic control, hyperglycemic } \\
\text { symptoms and quality of life in type } 2 \\
\text { diabetes (ZODIAC-2) }\end{array}$ & $\begin{array}{l}\text { To describe the relationship between } \\
\text { glycemic control, hyperglycemic } \\
\text { symptoms and quality of life in dia- } \\
\text { betic patients }\end{array}$ & $\begin{array}{l}\text { Observational, } \\
\text { cross-sectional }\end{array}$ & $\begin{array}{l}2005, \\
\text { Nether- } \\
\text { lands }\end{array}$ \\
\hline $\begin{array}{l}\text { Estudo } 6 \text { (E6) } \\
\text { STROBE: } 20 \text { items }\end{array}$ & $\begin{array}{l}\text { Association between glycaemic } \\
\text { control and quality of life in diabetes } \\
\text { mellitus }^{(21)}\end{array}$ & $\begin{array}{l}\text { To assess the association between } \\
\text { quality of life and change in A1c in } \\
\text { diabetic patients during a year }\end{array}$ & $\begin{array}{l}\text { Observational, } \\
\text { cohort }\end{array}$ & $\begin{array}{l}\text { 2004, } \\
\text { USA }\end{array}$ \\
\hline
\end{tabular}

USA: The United States of America; A1c: glycated haemoglobin.

Chart 3 - Distribution of studies according to the type of DM investigated, population size/sample, gender and mean age - São Paulo, SP, Brazil, 2015.

\begin{tabular}{|c|c|c|c|c|}
\hline Study & Type of Diabetes Mellitus & Population/sample & Gender & Mean age (SD) \\
\hline S1 & DM 2 & 282 & $\begin{array}{c}\text { Female } \\
\mathrm{n}=144(51.1 \%)\end{array}$ & $58.1 \pm 8.8$ \\
\hline S2 & DM 2 & 238 & $\begin{array}{c}\text { Female } \\
\mathrm{n}=148(62.2 \%)\end{array}$ & $58.7 \pm 9.6$ \\
\hline S3 & DM 2 & 164 & $\begin{array}{c}\text { Female } \\
\mathrm{n}=129(78.7 \%)\end{array}$ & $\begin{array}{c}\text { Female } \\
\mathrm{n}=95(85.6 \%)\end{array}$ \\
\hline S4 & DM 1 & 111 & $\begin{array}{c}\text { Female } \\
\mathrm{n}=662(57.6 \%)\end{array}$ & $48.5 \pm 7.9$ \\
\hline S5 & DM 2 & 1149 & $\begin{array}{c}\text { Female } \\
\mathrm{n}=561(50.3 \%)\end{array}$ & $68.7 \pm 11.5$ \\
\hline S6 & DM 1 & 1116 & $56.5 *$ \\
\hline
\end{tabular}

SD: standard deviation

* standard deviation not cited in the study

Chart 4 - Distribution of studies according to the evaluation of QOL instrument used, treatment adherence measures and influence of QOL in adherence - São Paulo, SP, Brazil, 2015.

\begin{tabular}{|l|l|l|l|}
\hline & $\begin{array}{l}\text { QOL } \\
\text { instrument }\end{array}$ & Adherence measure & $\begin{array}{c}\text { Influence } \\
\text { of QOL's in } \\
\text { adherence }\end{array}$ \\
\hline S1 & $\begin{array}{l}\text { - EQ-5D } \\
\text { - ADDQoL }\end{array}$ & A1c test & YES \\
\hline S2 & WHOQOL-100 & $\begin{array}{l}\text { - Indirect method of tablet count } \\
\text { - Knowledge of medical prescription on oral hypoglycemic dosage and frequency }\end{array}$ & NO \\
\hline S3 & $\begin{array}{l}\text { WHOQOL- } \\
\text { bref - Thai }\end{array}$ & $\begin{array}{l}\text { - A questionnaire containing information on diet control, exercise, medication use } \\
\text { and foot care }\end{array}$ & YES \\
\hline S4 & SF-12 & $\begin{array}{l}\text { Measured in accordance with guidelines of the American Diabetes Association (2005), which } \\
\text { includes two A1c tests, a cholesterol test, a microalbuminuria test and an eye examination }\end{array}$ & YES \\
\hline S5 & Rand-36 & A1c test & NO \\
\hline S6 & SF-36 & A1c test & YES \\
\hline
\end{tabular}

EQ-5D: Euroqol 5-D; ADDQoL: Audit of Diabetes-dependent Quality of Life; WHOQOL: World Health Organization Quality of Life instrument; SF-12: 12-Item Short-Form Health Survey; Rand-36: The RAND-36 Measure of Health-Related Quality of Life, SF-36: The 36-Item Short Form Health Survey; A1c: glycated hemoglobin; 
Results of study conducted in Singapore ${ }^{(23)}$ have shown that diabetics with lower $\mathrm{A} 1 \mathrm{c}$ values had better quality of life. Likewise, the research from Thailand ${ }^{(18)}$ identified association between good scores for quality of life and treatment adherence. The main factors related to worse QOL of diabetics were: low family income, use of insulin, longer

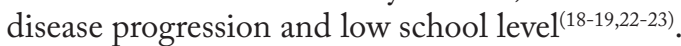

\section{DISCUSSION}

This review aimed to understand the relationship of QOL of diabetics with treatment adherence of the disease. In the selection of studies, we excluded 1149 references by title analysis. After screening 357 abstracts, 330 references were excluded, leaving 27 selected studies for full-text analysis. After full-text reading, 21 studies were excluded because they did not meet the inclusion criteria, therefore, six studies were included. Although the amount of studies initially retrieved was high (1507), the majority (76.2\%) was excluded from the review after reading the title. This result may be due to the interest of the scientific community on quality of life and treatment adherence topics, since the studies chose these descriptors. However, these studies were excluded because they did not investigate the relationship between these two variables.

In this review we chose to use only descriptors because they use a single language for indexing and retrieval of information in databases ${ }^{(24-25)}$, allowing recovery of studies that narrowly meet the objectives of this review.

Regarding the characterization of the six studies included in this review, all were observational ${ }^{(18-23)}$, with a predominance of cross-sectional studies ${ }^{(18,20,22-23)}$. In observational studies, the researcher does not intervene in the analyzed group because they would only be analysed in the epidemiological method of a natural experiment, noting the association between exposure and disease; because of that, they are low cost and its performance is fast, with easy application in relation to the experimental studies ${ }^{(26)}$.

$\mathrm{S}^{(18)}$ was the one with the lowest compliance (50\%) with the items in the STROBE, and information concerning the methodology was identified as weakness in the instrument checklist application.

The participants of the studies included in this review were mostly women (56.8\%). This can be explained by the fact that women are more frequently diagnosed with the disease than men due to their increased demand for health services $^{(5,27-28)}$.

Type $2 \mathrm{DM}$ was the most prevalent and the mean age of participants ranged from 44.7 to 68.7 years. This finding is supported by the profile of the disease. It is known that about $90 \%$ of the diabetics are type 2 , and that it affects mainly people over the age of 40 years ${ }^{(5,29-30)}$.

Different instruments were used to measure QOL, in general, they had physical (independence, ability to perform daily tasks, pain, vitality, well-being), psychological (emotional, mental health, anxiety/depression, social (environment, social aspects) and spiritual (religious) questions. The use of QOL assessment instruments provides real and concrete assessment of the overall impact that the disease causes in individuals' lives and its main advantage include subjective aspects that are not identified by other evaluation methods ${ }^{(31)}$. The use of generic and specific instruments have advantages and disadvantages in measuring the QOL of patients with DM. Specific instruments include the symptoms and dysfunctions characteristics of the DM; however, they are restricted to these aspects, preventing an QOL overview. Also, they do not allow comparison between diabetic and non-diabetic individuals. In the literature, there is no consensus about the best instrument to assess QOL of diabetics ${ }^{(4)}$.

In this review, there was a relationship between QOL and treatment adherence in $\mathrm{S} 1^{(23)}, \mathrm{S} 3^{(18)}, \mathrm{S} 4^{(19)}$ and $\mathrm{S} 6^{(21)}$. The results of $\mathrm{S} 4^{(19)}$ and $\mathrm{S} 5^{(20)}$ showed that the mental health domain of the SF-12 and SF-36 instruments were related to treatment adherence.

$\mathrm{S} 4^{(19)}$ found a negative association between mental health domain of the SF-12 and treatment adherence of diabetics. $\mathrm{S} 6^{(21)}$ identified a positive association between mental health measured by the SF-36 and treatment adherence. Despite presenting discordant results, the findings about the psychological domain with the treatment adherence are in accordance with the results of another study ${ }^{(30)}$ which found that diabetics with better scores on the psychological dimension of the WHOQOL-Bref kept better glycemic control.

Researchers ${ }^{(32-33)}$ found that the SF-12, even though seem as a generic instrument for assessing QOL, demonstrates a level of sensitivity and high reliability, thus validating its structure. One hypothesis that could explain this difference in results between $\mathrm{S} 4^{(19)}$ and $\mathrm{S}^{(21)}$ is that studies do not apply the same version of the instruments and analyze sample size and mean age differently: $\mathrm{S}^{(19)}$ used the SF-12 as a measure of QOL assessment in a sample of 111 participants with a mean age 44.7 years. While $\mathrm{S} 6^{(21)}$ used the SF-36 in a population 10 times larger $(n=1116)$ than the previous study and with higher mean age of participants: approximately 56 years.

The lower A1c was associated with better QOL in $\mathrm{S} 1^{(23)}$ and $\mathrm{S6}^{(21)}$. The $\mathrm{A} 1 \mathrm{c}$ is an important parameter for glycemic control in patients with DM. The A1c is strongly related to the onset and progression of chronic complications of $\mathrm{DM}^{(34)}$. Assuming that diabetic patients with lower levels of A1c have better QOL, it can be inferred that individuals in the sample of these studies are more adherent to treatment of the disease.

Although A1c is a good glycemic control parameter, there are currently other methods to assess adherence to the therapeutic regimen, such as the questionnaire for treatment adherence, Summary of Diabetes Self-Care Activities Questionnaire (SDSCA), and the questionnaire Treatment Measure Adherence (TMA). These adherence questionnaires are effective in assessing treatment adherence since they are based on self-reporting answers and use specific questions that cover major self-care activities of the diabetic patient ${ }^{(29,35)}$.

The metabolic control is complex and depends on the effective implementation of various actions, such as dietary control, physical exercise, proper follow-up of drug treatment, among others. However, this review found only one 
study $(\mathrm{S} 3)^{(18)}$ which used such actions as treatment adherence. Obtaining a good DM metabolic control prevents the onset or slow down the progression of diabetes complications ${ }^{(36)}$.

There was no association between QOL and treatment adherence in $\mathrm{S} 2^{(22)}$ and $\mathrm{S} 5^{(20)}$. It can be inferred that the use of an indirect method to measure treatment adherence, as used in S2, may have affected this result. In this sense, it is assumed that analyzing only tablet counts and knowledge of the patient on medical prescription are not considered good parameters for metabolic control.

The negative association between glucose symptoms and QOL was the main result found in $\mathrm{S} 5^{(20)}$. It is difficult to explain the absence of the relationship between QOL and DM adherence, especially considering the negative relationship between glycemic symptoms and QOL found in the study. Participants in the studies that had higher frequency of blood glucose symptoms such as hyperglycemia, had lower QOL levels and higher levels of A1c, but there was no association between the deterioration of QOL of patients with treatment adherence.

The insulin was the only type of treatment associated with worsening of diabetic $\mathrm{QOL}^{(23)}$, this is due to the pain reported by patients related to the application of the drug. Studies $^{(4,37)}$ corroborate this finding as they establish that the insulin use resulted in pain and side effects such as lipo- dystrophy, factors impacting on the individual's self-esteem, thus influencing the psychological and physical aspects.

As limitations of this systematic review, we emphasize the language restriction (English, Portuguese and Spanish) and the publication period (2003-2014), in addition to the exclusive use of descriptors in the databases.

\section{CONCLUSION}

The influence of the diabetic patient's QOL on treatment adherence was identified in four of the six studies included. The best QOL was associated with treatment adherence of DM since three studies used different assessment instruments (EQ-5D, ADDQoL, WHOQOL-bref-Thai and SF-36). An investigation found that the worse QOL, according to the mental component of the SF-12, was negatively associated with treatment adherence of the disease.

Health professionals need to pay attention to the dimensions of QOL that are most affected in patients with DM and intervene early on, since this aspect may play negative influence on treatment adherence of the disease.

Through the findings of this review, it is possible to infer that studies with larger sample sizes and longer follow-ups could generate more relevant clinical findings and more clearly elucidate the relationship between quality of life, glycemic control and treatment adherence.

\section{RESUMO}

Objetivo: Verificar a influência da qualidade de vida na adesão ao tratamento do paciente com diabetes mellitus. Método: Revisão sistemática da literatura nas bases de dados MEDLINE, CINAHL, SCOPUS, LILACS, SciELO e Web of Science de estudos publicados entre 2003 e 2014 nos idiomas inglês, português ou espanhol. Resultados: Foram incluídos seis estudos na revisão, sendo que três identificaram que melhores escores de qualidade de vida estão relacionados com melhor adesão ao tratamento do diabetes mensurada pela hemoglobina glicada ou características relacionadas à dieta, a exercícios, ao uso de medicamentos e aos cuidados com os pés. Não foi encontrada associação entre qualidade de vida e adesão em duas investigações, e um estudo encontrou associação negativa entre essas variáveis. Conclusão: Existe relação causal entre a qualidade de vida e o cumprimento do tratamento do diabetes. Sugere-se que aspectos psicossociais dos pacientes devam ser considerados pelos profissionais de saúde na busca por melhores resultados clínicos no tratamento do diabetes.

\section{DESCRITORES}

Diabetes Mellitus; Qualidade de Vida; Cooperação do Paciente; Adesão à Medicação; Revisão.

\section{RESUMEN}

Objetivo: Verificar la influencia de la calidad de vida en la adhesión al tratamiento del paciente con diabetes mellitus. Método: Revisión sistemática de la literatura en las bases de datos MEDLINE, CINAHL, SCOPUS, LILACS, SciELO y Web of Science de estudios publicados entre 2003 y 2004 en los idiomas inglés, portugués o español. Resultados: Fueron incluidos seis estudios en la revisión, siendo que tres identificaron que mejores puntajes de calidad de vida están relacionados con mejor adhesión al tratamiento de la diabetes medida por la hemoglobina glicada o características relacionadas con la dieta, ejercicios, uso de fármacos y cuidados con los pies. No fue encontrada asociación entre calidad de vida y adhesión en dos investigaciones, y un estudio encontró asociación negativa entre dichas variables. Conclusión: Existe relación causal entre la calidad de vida y el cumplimiento del tratamiento de la diabetes. Se sugiere que los profesionales sanitarios deben considerar los aspectos psicosociales de los pacientes en la búsqueda por mejores resultados clínicos en el tratamiento de la diabetes.

\section{DESCRIPTORES}

Diabetes Mellitus; Calidad de Vida; Cooperación del Paciente; Cumplimiento de la Medicación; Revisión.

\section{REFERENCES}

1. Brasil. Ministério da Saúde; Secretaria de Atenção à Saúde, Departamento de Atenção Básica. Estratégias para o cuidado da pessoa com doença crônica: diabetes mellitus. Brasília: MS; 2013.

2. World Health Organization, Study Group on Integration on Health Care Delivery. Report WHO - 10 facts about diabetes [Internet]. 2013 [cited 2015 Jan 20]. Available from: http://www.who.int/features/factfiles/diabetes/en/ 
3. Farias MS, Agra CCM, Araújo LK, Correia DS, Cavalcante JC. Treatment adherence and life quality of diabetic patients assisted in the primary care division. Rev Soc Bras Clín Med. 2014;12(2):102-7.

4. Aguiar, CCT, Vieira APGF, Carvalho AF, Montenegro Junior RM. Instrumentos de avaliação de qualidade de vida relacionados à saúde no diabetes mellitus. Arq Bras Endocrinol Metab. 2008;52(6):931-9.

5. Correr CJ, Pontarolo R, Melchiors AC, Rossignoli P, Fernández FL, Radominski RB. Tradução para o português e validação do instrumento Diabetes Quality of Life Measure (DQOL-Brasil). Arq Bras Endocrinol Metab. 2008;52(3):515-22.

6. Miranzi SSC, Ferreira FS, Iwamoto HH, Pereira GA, Miranzi MAS. Qualidade de vida de indivíduos com diabetes mellitus e hipertensão acompanhados por uma equipe de saúde da família. Texto Contexto Enferm. 2008;17(4):672-9.

7. Surwit RS, van Tilburg MA, Zucker N, McCaskill CC, Parekh P, Feinglos MN, et al. Stress management improves long-term glycemic control in type 2 diabetes. Diabetes Care. 2002;25(1):30-4.

8. Seidl EMF, Zannon CMLC. Qualidade de vida e saúde: aspectos conceituais e metodológicos. Cad Saúde Pública. 2004;20(2):580-8.

9. World Health Organization. WHOQOL Group. The development of the World Health Organization quality of life assessment instrument (the WHOQOL). In: Orley J, Kuyken W, editors. Quality of life assessment: international perspectives. Heigelberg: Springer Verlag; 1994. p. 41-60.

10. Ramos L, Ferreira EAP. Fatores emocionais, qualidade de vida e adesão ao tratamento em adultos com diabetes tipo 2. Rev Bras Crescimento Desenvolv Hum. 2011;21(3):867-77.

11. Hassan K, Loar R, Anderson BJ, Heptulla RA. The role of socioeconomic status, depression, quality of life, and glycemic control in type 1 diabetes mellitus. J Pediatr. 2006;149(4):526-31.

12. Skinner TC, Hoey H, McGee HM, Skovlund SE. A short form of the Diabetes Quality of Life for Youth questionnaire: exploratory and confirmatory analysis in a sample of 2,077 young people with type 1 diabetes mellitus. Diabetologia. 2006;49(4):621-8.

13. Puri K, Sapra S, Jain V. Emotional, behavioral and cognitive profile, and quality of life of Indian children and adolescents with type 1 diabetes. Indian J Endocrinol Metab. 2013;17(6):1078-83.

14. O'Neil KJ, Jonnalagadda SS, Hopkins BL, Kicklighter JR. Quality of life and diabetes knowledge of young persons with type 1 diabetes: influence of treatment modalities and demographics. J Am Diet Assoc. 2005;105(1):85-91.

15. Lopes ALM, Fracolli LA. Revisão sistemática de literatura e metassíntese qualitativa: considerações sobre sua aplicação na pesquisa em enfermagem. Texto Contexto Enferm. 2008;17(4):771-8.

16. Santos CMC, Pimenta CAM, Nobre MRC. A estratégia PICO para a construção da pergunta de pesquisa e busca de evidências. Rev Latino Am Enfermagem. 2007;15(3):508-11.

17. Malta M, Cardoso LO, Bastos FI, Magnanini MMF, Silva CMFP. STROBE initiative: guidelines on reporting observational studies. Rev Saúde Pública. 2010;44(3):559-65.

18. Chaveepojnkamjorn W, Pichainarang N, Schelp FP, Mahaweerawat U. Quality of life and compliance among type 2 diabetic patients. Southeast Asian J Trop Med Public Health. 2008;39(2):328-34.

19. Honish A, Westerfield W, Ashby A, Momin S, Phillippi R. Health-related quality of life and treatment compliance with diabetes care. Dis Manag. 2006;9(4):195-200.

20. Kleefstra N, Ubink-Veltmaat LJ, Houweling ST, Groenier K, Meyboom-de JB, Bilo HJ. Cross-sectional relationship between glycaemic control, hyperglycaemic symptoms and quality of life in type 2 diabetes (ZODIAC-2). Neth J Med. 2005;63(6):215-21.

21. Lau CY, Qureshi AK, Scott SG. Association between glycaemic control and quality of life in diabetes mellitus. J Postgrad Med. 2004;50(3):189-94.

22. Martínez YV, Prado-Aguilar CA, Rascón-Pacheco RA, Valdivia-Martínez JJ. Quality of life associated with treatment adherence in patients with type 2 diabetes: a cross-sectional study. BMC Health Serv Res. 2008;8:164.

23. Shim YT, Lee J, Toh MP, Tang WE, Ko Y. Health-related quality of life and glycaemic control in patients with Type 2 diabetes mellitus in Singapore. Diabet Med. 2012; 29(8):241-8.

24. Brandau R, Monteiro R, Braile DM. Importância do uso correto dos descritores nos artigos científicos. Rev Bras Cir Cardiovasc. 2005;20(1):79.

25. Pereira TA, Montero EFS. Terminologia DeCS e as novas regras ortográficas da língua portuguesa: orientações para uma atualização. Acta Cir Bras. 2012;27(7):509-14.

26. Lima-Costa MF, Barreto SM. Tipos de estudos epidemiológicos: conceitos básicos e aplicações na área do envelhecimento. Epidemiol Serv Saúde. 2003;12(4):189-201.

27. Akinci F, Yildirim A, Gözü H, Sargin H, Orbay E, Sargin M. Assessment of health-related quality of life (HRQoL) of patients with type 2 diabetes in Turkey. Diabetes Res Clin Pract. 2008;79(1):117-23.

28. Wild S, Roglic G, Green A, Sicree R, King H. Global prevalence of diabetes: estimates for the year 2000 and projections for 2030 . Diabetes Care. 2004;27(5):1047-53.

29. Gimenes HT, Zanetti ML, Haas VJ. Factors related to patient adherence to antidiabetic drug therapy. Rev Latino Am Enfermagem. 2009;17(1):46-51.

30. Faria HTG, Veras VS, Xavier ATF, Teixeira CRS, Zanetti ML, Santos MA. Quality of life in patients with diabetes mellitus before and after their participation in an educational program. Rev Esc Enferm USP. 2013;47(2):348-54.

31. Santos AMB, Assumpção A, Matsutani LA, Pereira CAB, Lage LV, Marques AP. Depressão e qualidade de vida em pacientes com fibromialgia. Rev Bras Fisioter. 2006;10(3):317-24. 
32. Gandek B, Ware JE, Aaronson NK, Apolone G, Bjorner JB, Brazier JE, et al. Cross-validation of Item selection and scoring for the SF-12 Health Survey in nine countries: results from the IQOLA Project. J Clin Epidemiol. 1998;51(11):1171-8.

33. Silveira MF, Almeida JC, Freire RS, Haikal DS, Martins AELB. Propriedades psicométricas do instrumento de avaliação da qualidade de vida: 12-item health survey (SF-12). Ciênc Saúde Coletiva. 2013;18(7):1923-31.

34. Camargo JL, Gross JL. Glico-hemoglobina (HbA1c): aspectos clínicos e analíticos. Arq Bras Endocrinol Metab. 2004;48(4):451-63.

35. Michels MJ, Coral MHC, Sakae TM, Damas TB, Furianetto LM. Questionário de Atividades de Autocuidado com o Diabetes: tradução, adaptação e avaliação das propriedades psicométricas. Arq Bras Endocrinol Metab. 2010;54(7):644-51.

36. Sociedade Brasileira de Diabetes. Diretrizes da Sociedade Brasileira de Diabetes: 2013-2014. São Paulo: AC Farmacêutica; 2014.

37. Mata CM, Roset GM, Badia LX, Antonanzas VF, Ragel AJ. Effect of type-2 diabetes mellitus on the quality of life of patients treated at primary care consultations in Spain. Aten Primaria. 2003;31(8):493-9. 